\title{
Analisis Penambahan Resolusi Digital Elevation Model (DEM) dengan Menggunakan Metode Interpolasi Inverse Distance Weighted (IDW) untuk Aplikasi Analisis Potensi Longsoran
}

\author{
Rustan $^{1, a)}$ dan Acep Purqon ${ }^{2, b)}$ \\ ${ }^{1}$ Magister Fisika, FMIPA ITB \\ ${ }^{2}$ Fisika Bumi dan Sistem Kompleks, FMIPA ITB \\ a)rustankabaro@yahoo.com (corresponding author) \\ b)acep@fi.itb.ac.id
}

\begin{abstract}
Abstrak
Informasi ketinggian suatu tempat di permukaan bumi (elevasi) merupakan hal yang sangat penting di dalam analisis geospasial. Data elevasi tersebut umumnya disimpan dalam bentuk Digital Elevation Model (DEM). DEM selanjutnya diintegrasikan dengan data geospasial lainnya di dalam GIS untuk berbagai keperluan. Lembaga formal seperti USGS, NASA, METI secara aktif melakukan pengambilan data DEM melalui teknologi satelit dan menyediakan data DEM secara global dan dapat diperoleh secara online. Namun demikian, umumnya DEM yang tersedia secara gratis adalah DEM dengan ketelitian piksel $30 \mathrm{~m}$ atau lebih besar. Khusus untuk wilayah Indonesia, ketersediaan data DEM dengan resolusi yang lebih tinggi masih sangat minimal. Padahal data DEM resolusi tinggi dibutuhkan untuk berbagai macam aplikasi misalnya sebagai data input dalam pemodelan debris flow. Pembuatan DEM dengan resolusi yang lebih tinggi dapat dilakukan melalui interpolasi titik ketinggian. Data digital berupa ketinggian yang didapat dari DEM SRTM $30 \mathrm{~m}$ dalam bentuk format raster diekstrak di ArcMap kemudian diubah menjadi data format point sebagai input untuk proses interpolasi. Pada penelitian ini, akan dilakukan pembuatan DEM resolusi $5 \mathrm{~m}$ menggunakan metode interpolasi Inverse Distance Weighted (IDW). Penelitian ini dilakukan pada daerah yang rawan longsor di Jawa Barat. Akurasi hasil interpolasi dilakukan dengan membandingan DEM sebelum interpolasi baik secara kualitatif dan kuantitatif. Tingkat akurasi hasil interpolasi data DEM secara kuantitatif dinyatakan dalam RMSE (Root Mean Square Error).
\end{abstract}

Kata-kata kunci: DEM, debris flow, interpolasi, GIS

\section{PENDAHULUAN}

Data ketinggian (elevasi) merupakan data ketinggian suatu titik pada permukaan bumi yang diukur dari atas permukaan laut [1]. Informasi mengenai ketinggian suatu tempat merupakan hal yang sangat penting dan dibutuhkan dalam berbagai bidang, antara lain pemetaan sumber daya lahan [2], pemetaan jaringan sungai [3,4], pemodelan dan simulasi banjir [5], simulasi luas genangan debris flow [6], dan lain-lain. Pada awalnya, data elevasi disimpan dalam bentuk peta analog dan garis-garis kontur secara manual. Seiring perkembangan teknologi komputer, data ketinggian tersebut disimpan dalam bentuk digital sehingga disebut Digital Elevation Model (DEM) [4]. DEM merupakan data format raster dan memiliki banyak jenis, namun yang paling umum digunakan yaitu ASTER GDEM dan DEM SRTM. Kedua jenis data DEM tersebut dapat didownload secara gratis di internet sampai resolusi $30 \mathrm{~m}$ (ukuran piksel $30 \mathrm{~m} \times 30 \mathrm{~m}$ ). Namun dalam 
berbagai aplikasi seperti simulasi genangan debris flow, dibutuhkan DEM dengan resolusi yang lebih detail yaitu kurang dari $10 \mathrm{~m}$ [6]. DEM yang lebih detail dapat dihasilkan dengan cara interpolasi.

Pada prinsipnya, interpolasi dilakukan untuk menentukan titik-titik yang belum diketahui nilainya berdasarkan titik-titik tetangga yang sudah diketahui nilainya. Ada beberapa jenis teknik interpolasi yang umum digunakan seperti metode Inverse Distance Weighted (IDW), Natural Neighbour, Spline, dan Kryging [5]. Masing-masing metode memiliki kelebihan dan kekurangan masing-masing. Hasil akhir yang ingin dicapai dari proses interpolasi adalah untuk menciptakan model permukaan yang semakin merepresentasikan permukaan bumi yang sebenarnya.

Pada penelitian ini, interpolasi data DEM dilakukan untuk selanjutnya digunakan sebagai data masukan pada penelitian lebih lanjut pada pemodelan genangan debris flow. Data yang akan diinterpolasi adalah DEM Shuttle Radar Topography Mission (SRTM) 30 m. DEM SRTM dengan resolusi spasial 30 m ini selanjutnya akan diinterpolasi menggunakan metode Inverse Distance Weighted (IDW) menggunakan software ArcMap 10.1 untuk menghasilkan DEM dengan resolusi spasial 5 m. Daerah penelitian adalah desa Margamukti yang pernah mengalami longsoran di Pangalengan, Jawa Barat.

\section{LANDASAN TEORI DAN METODE}

\section{Digital Elevation Model (DEM)}

DEM merupakan model 3 dimensi bentuk permukaan bumi, digambarkan dengan susunan sel teratur dan berukuran seragam (persegi, segitiga, dll) [4]. Setiap sel memiliki koordinat spasial (x,y) dan mewakili nilai ketinggian tertentu (z). Nilai ketinggian biasanya terletak di tengah-tengah sel. Ukuran sel menunjukkan resolusi yang merupakan karakteristik tingkat kedetailan DEM. Semakin kecil ukuran sel semakin tinggi resolusi dan detail DEM, sehingga semakin merepresentasikan bentuk permukaan bumi yang sebenarnya [7].

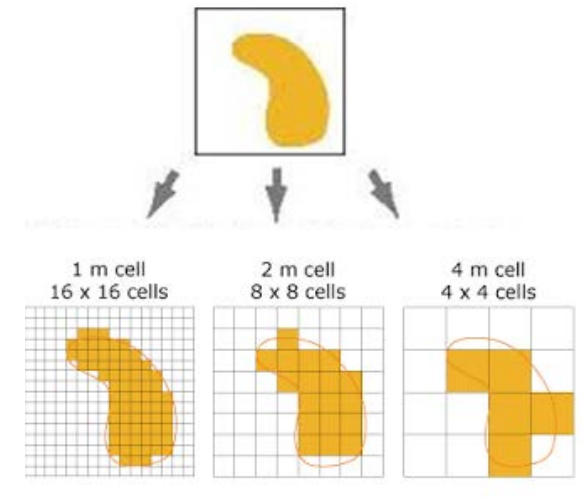

Gambar 1. Pengaruh ukuran sel terhadap resolusi data raster DEM [8]

Data DEM umumnya dapat diperoleh dengan mendownload di internet. Data DEM yang paling umum digunakan yaitu ASTER GDEM dan DEM SRTM karena tersedia secara global dan meliputi hampir seluruh permukaan bumi. Advanced Spaceborne Thermal Emission and Reflection Radiometer Global Digital Elevation Model (ASTER GDEM) merupakan data raster hasil perekaman satelit ASTER, tersedia secara gratis dan wilayahnya mencakup seluruh permukaan bumi termasuk Indonesia. Resolusi yang tersedia secara gratis yaitu 1 arc sec $(30 \mathrm{~m} \times 30 \mathrm{~m})$ dan dapat didownload di internet dengan alamat situs www.gdem.aster.ersdac.or.jp. DEM Shuttle Radar Topography Mission (SRTM) merupakan DEM yang dihasilkan NASA dan NGA (National Geospatial-Intelligence Agency) atas kerjasama dengan badan antariksa Italia dan Jerman. Proses pengambilan dilakukan menggunakan radar. DEM SRTM memiliki resolusi 3 arc sec $(90 \mathrm{~m} \times 90 \mathrm{~m}$ ). Sejak september 2014, DEM SRTM tersedia produk data ketinggian resolusi spasial $30 \mathrm{~m}$ yang disebut SRTM 1 Arc-second secara global, dan dapat didownload di www.earthexplorer.usgs.gov [4].

\section{Interpolasi IDW}

Interpolasi merupakan teknik untuk mengestimasi nilai suatu titik yang belum diketahui nilainya berdasarkan titik-titik tetangga yang diketahui nilanya. Proses interpolasi digunakan untuk menghasilkan citra yang lebih detail [9]. 


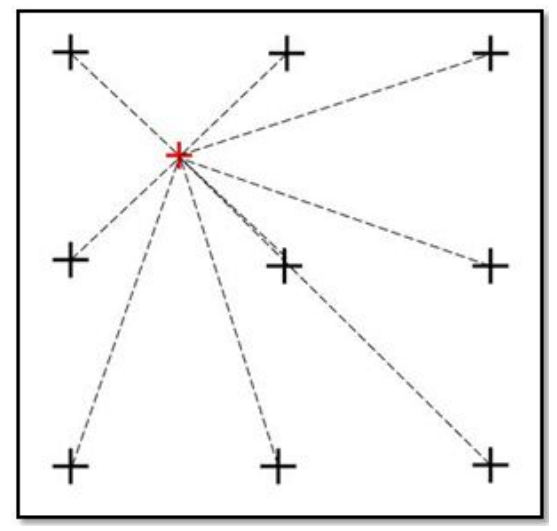

Gambar 2. Interpolasi untuk estimasi nilai suatu titik tertentu

Interpolasi Inverse Distance Weighted (IDW) merupakan salah satu jenis teknik interpolasi yang bersifat lokal. Nilai titik estimasi dipengaruhi oleh titik-titik tetangga dimana titik yang jaraknya lebih dekat memberi pengaruh (bobot) yang lebih besar dan bobot akan berkurang seiring bertambahmya jarak. Bobot $\left(\omega_{i}\right)$ menyatakan besar pengaruh titik tetangga pada titik estimasi [10]. Persamaan yang digunakan dalam metode interpolasi IDW yaitu [9]:

$$
z(x, y)=\sum_{i=1}^{N} \omega_{i} z\left(x_{i}, y_{i}\right)
$$

dimana $z(x, y)$ adalah nilai ketinggian estimasi pada titik $(x, y), z\left(x_{i}, y_{i}\right)$ adalah data titik ketinggian yang ingin diinterpolasi sejumlah $\mathrm{N}$ titik, dan $\omega_{i}$ adalah bobot (weight) titik data. Bobot dirumuskan sebagai berikut:

$$
\omega_{i}=\frac{h_{i}^{-p}}{\sum_{i=1}^{N} h_{i}^{-p}}
$$

dimana $p$ adalah parameter power yang nilainya dapat diubah-ubah, $h_{i}$ adalah jarak titik data ke titik estimasi, yang dapat dihitung menggunakan persamaan pythagoras sebagai berikut:

$$
h_{i}=\sqrt{\left(x-x_{i}\right)^{2}+\left(y-y_{i}\right)^{2}}
$$

Kelebihan interpolasi IDW adalah jumlah titik-titik tetangga yang berpengaruh dapat dibatasi. Titik-titik yang jauh dari titik estimasi dan dianggap kurang berkorelasi atau tidak memiliki korelasi sama sekali bisa dihilangkan dari perhitungan. Kelemahan interpolasi IDW yaitu tidak dapat mengestimasi nilai diatas nilai maksimum dan dibawah nilai minimum dari titik-titik sampel [4].

Prinsip interpolasi IDW ini sudah terintegrasi dengan perangkat lunak ArcMap. Di dalam ArcMap, proses interpolasi dilakukan secara otomatis dengan menggunakan fungsi raster interpolation pada menu Spatial Analyst.

Tingkat akurasi DEM dilakukan dengan cara membandingkan DEM sebelum interpolasi dengan setelah interpolasi atau cross validation (validasi silang). Salah satu pendekatan statistik untuk menentukan akurasi DEM yaitu Root Mean Square Error (RMSE). Ukuran ini paling sering digunakan untuk membandingkan akurasi model dalam analisis spasial. RMSE merupakan standar deviasi ketinggian antara data DEM sebelum dan setelah interpolasi, dirumuskan [11]:

$$
R M S E=\sqrt{\frac{\sum\left(z_{i}-z_{t}\right)^{2}}{N}}
$$

dimana $Z_{i}$ adalah titik-titik ketinggian hasil interpolasi, $Z_{t}$ adalah titik ketinggian setelah interpolasi, dan $N$ adalah jumlah titik data. Semakin kecil nilai RMSE menandakan semakin akurat hasil interpolasi tersebut [12]. 


\section{Data Penelitian}

Data penelitian yaitu data DEM SRTM 30 m desa Margamukti, Kecamatan Pangalengan, Jawa Barat. Terletak di kordinat $107^{\circ} 37^{\prime} 54,3$ ” BT dan 07²1'24,0” LS. Data DEM didownload di alamat www.earthexplorer.usgs.gov dengan terlebih dahulu melakukan registrasi. Data tersebut dalam format raster dan berekstensi .tif. Berikut tampilan data DEM untuk desa Margamukti dengan resolusi spasial 30 m:

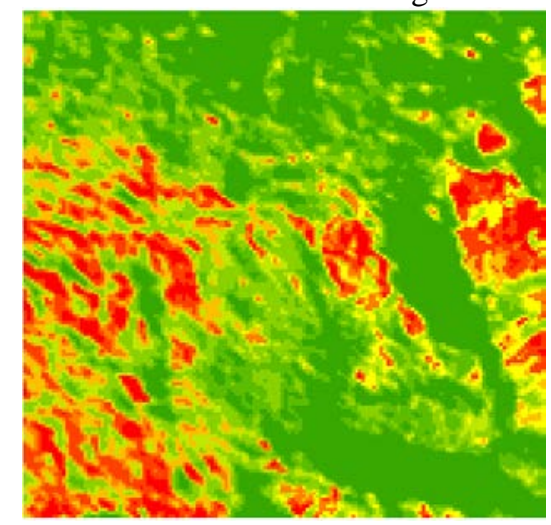

Gambar 3. DEM lokasi penelitian dalam resolusi 30 m (format raster)

Data DEM tersebut kemudian diolah menggunakan software ArcMap 10.1. Agar dapat dilakukan interpolasi, data DEM dalam format raster harus diubah ke dalam format titik (point) menggunakan menu "Conversion Tool $\rightarrow$ From Raster to Point" pada bagian kanan menu tool ArcMap. Setelah DEM dalam format point, maka dapat dilakukan interpolasi IDW dengan menggunakan menu "Spatial Analyst $\rightarrow$ Interpolation $\rightarrow$ IDW", sehingga dihasilkan data DEM dengan resolusi spasial 5 m. Selain itu, tampilan DEM bisa dilakukan secara hillshade yaitu efek bayangan suatu permukaan.

\section{HASIL DAN PEMBAHASAN}

Tampilan data DEM dalam format point sebelum dilakukan interpolasi dan setelah dilakukan interpolasi. Pada saat sebelum interpolasi, jarak antara dua titik berdekatan sejauh $30 \mathrm{~m}$, dan tidak ada data nilai ketinggian antara dua titik tersebut. Setelah dilakukan interpolasi, jarak antar data titik ketinggian menjadi semakin rapat sebesar $5 \mathrm{~m}$ serta didapatkan nilai data titik yang semakin banyak.

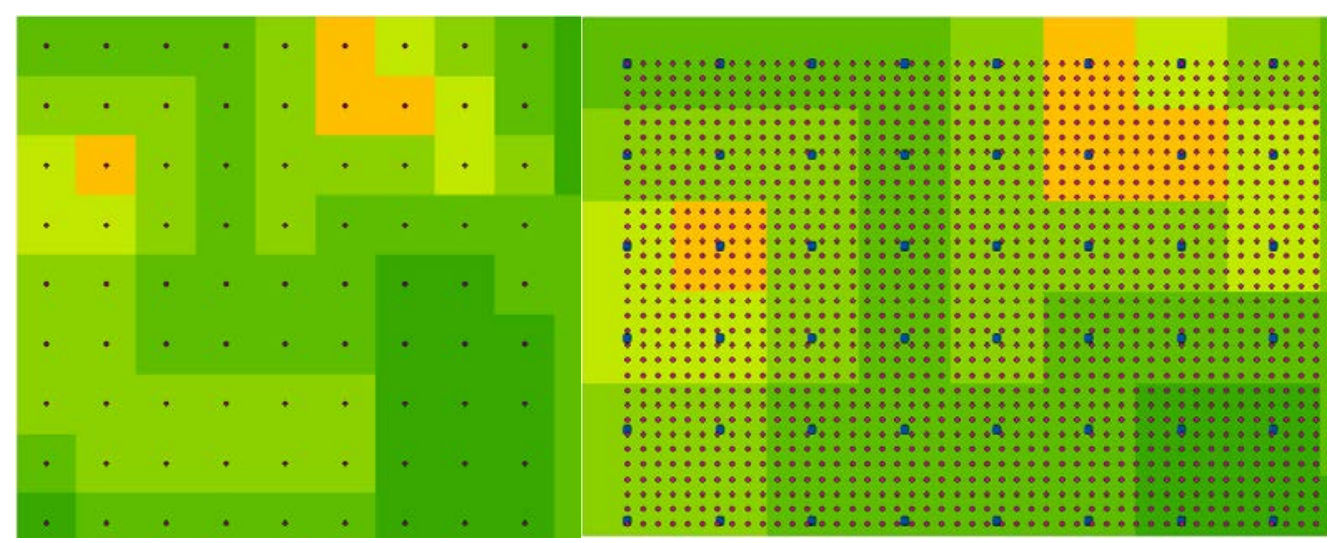

Gambar 4. Data DEM dalam format point: sebelum interpolasi IDW (kiri) dan setelah interpolasi IDW (kanan) 


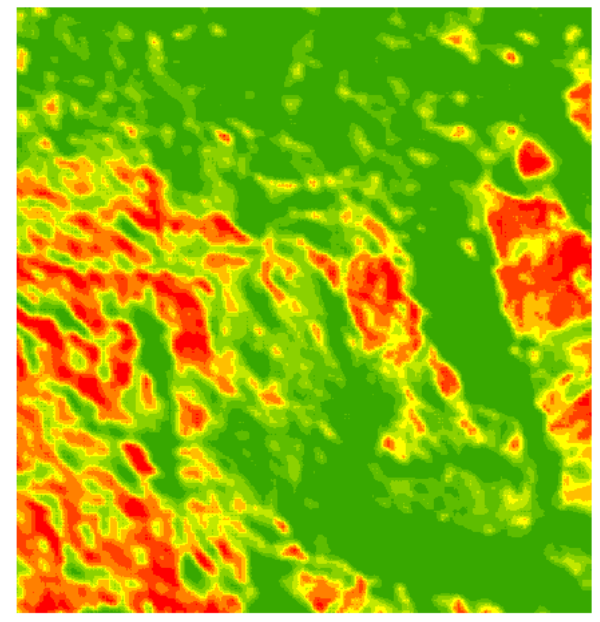

Gambar 5. Tampilan DEM 5 m setelah interpolasi IDW

Tampilan hillshade merupakan efek bayangan suatu permukaan untuk mempertajam visualisasi citra. Gambar 6 menampilkan perbandingan visual secara hillshade antara DEM sebelum dan setelah dilakukan interpolasi IDW. Hillshade di gambar 6 memperlihatkan DEM hasil interpolasi dengan resolusi 5 m memiliki tampilan yang lebih tajam dibandingkan sebelum interpolasi yang masih buram (blur).

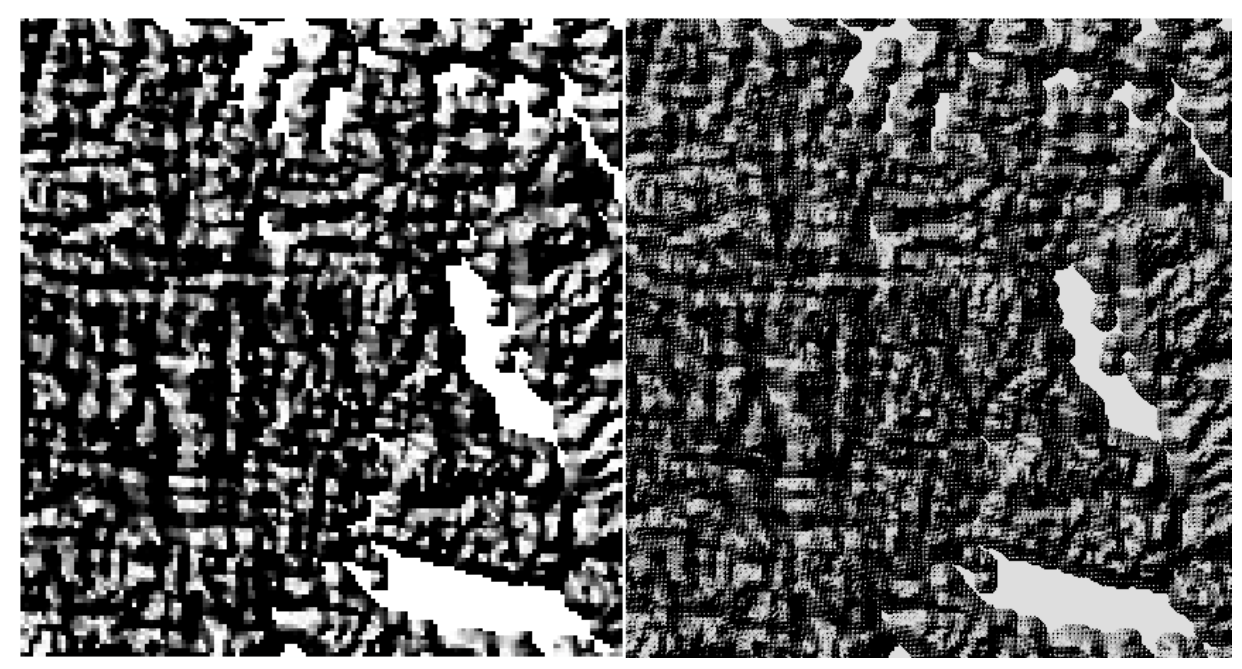

Gambar 6. Data DEM dalam tampilan Hillshade: sebelum interpolasi IDW (kiri) dan setelah interpolasi IDW (kanan)

Nilai RMSE (Root Mean Square Error) dihitung untuk 100 data titik sebelum dan setelah interpolasi dan didapatkan nilai 43.25, termasuk kategori besar.

\section{KESIMPULAN}

Data DEM dengan resolusi 30 m dapat diinterpolasi untuk menghasilkan DEM dengan resolusi yang lebih tinggi. Proses interpolasi akan menghasilkan data pada titik yang sebelumnya belum diketahui nilainya. Semakin banyak titik ketinggian yang diketahui akan membuat data DEM semakin detail. Untuk menghasilkan DEM resolusi 5 m dapat dilakukan dengan interpolasi Inverse Distance Weighted (IDW).

\section{REFERENSI}

1. CSPCWG Chairman, S-32: The definitions of Altitude, Elevation and Height. $4^{\text {th }}$ IHO-HSSCMeeting, Taunton, UK (2012)

2. R. Shofiyati dan W. Supriatna, Pemanfaatan Data Unduhan Gratis dari Internet untuk Penelitian Sumber Daya Lahan. Informatika Pertanian Vol. 20 No. 1 (2011) 
3. Z. Han, R. Tenges, S. Hallmark, R. Souleyrette, dan S. Pattnaik, Use of LiDAR-Based Elevation Data for Highway Drainage Analysis: A Qualitative Assessment. Proceedings of the 2003 Mid-Continent Transportation Research Symposium, Iowa (2003)

4. Indarto dan D.R. Prasetyo, Pembuatan Digital Elevation Model Resolusi 10 m dari Peta RBI dan Survei GPS dengan Algoritma ANUDEM. Jurnal Keteknikan Pertanian Vol. 28 No. 1 (2014)

5. J. M. Siregar dan N.S. Haryani, Perbandingan Teknik Interpolasi DEM SRTM dengan Metode Inverse Distance Weighted (IDW), Natural Neighbor, dan Spline . Jurnal Penginderaan Jauh Vol. 9 No. 2 (2012)

6. M. Berti dan A.Simoni, DFLOWZ: A Free Program to Evaluate The Area Potentially Inundated by A Debris Flow,Computer and Geoscience 67 (2014)

7. J.C. Guarneri dan R.C. Weih, Comparing Methods for Interpolation to Improve Raster Digital Elevation Models. Journal of Arkansas Academy of Science, Vol. 06 (2012)

8. http://desktop.arcgis.com/en/arcmap/10.3/manage-data/raster-and-images/cell-size-of-raster-data.htm

9. $\quad$ P.A. Borrough dan R.A. McDonnell, Principle of Geographical Information Systems, Oxford University Press (1998)

10. A. Setianto dan T. Triandini, Comparison of Kryging and Inverse Distance Weighted (IDW) Interpolation Methods in Lineament Extraction and Analysis. J. SE Asian Appl. Geol. (2013)

11. I. Linuza, Accuracy Assessment in Glacier Change Analysis. Thesis, Lund University Sweden (2014)

12. A.A. Khusnawati, Evaluasi dan Perencanaan Kerapatan Jaringan Pos Hujan dengan Metode Kriging dan Analisa Bobot (Score) di Wilayah Sungai Palu-Lariang Provinsi Sulawesi Tengah. Universitas Brawijaya Malang (2015) 